\title{
PEMBINAAN GURU-GURU SENI BUDAYA SMPN SUNGAI PUA KABUPATEN AGAM SEBAGAI UPAYA MENINGKATKAN KUALITAS PEMBELAJARAN
}

\author{
Zubaidah $^{1 *}$, Yusron Wikarya ${ }^{2 *}$, Abd. Hafiz ${ }^{3^{*}}$ \\ Program Studi Pendidikan Seni Rupa Jurusan Seni Rupa Fakultas Bahasa dan Seni \\ Universitas Negeri Padang \\ Jl. Prof. Dr. Hamta, Air Tawar Padang, Kel. Air Tawar Barat, Kec. Padang Utara, Kota Padang, Kode Pos 25171 \\ Sumatera Barat. Indonesia \\ Email: zubaidah@gmail.com
}

\begin{abstract}
Abstrak
Permasalahan mendasar yang dialami oleh guru-guru seni budaya di SMP Sungai Pua Kabupaten Agam khususnya SMPN 1 dan SMPN 2 adalah dalam meningkatkan kualitas pembelajaran, sehingga berdampak pada pencapaian hasil belajar siswa. Salah satu upaya untuk meningkatkan kualitas pembelajaran tersebut adalah dengan melaksanakan PTK. Pada umumnya guru SMP Sungai Pua belum melaksanakan PTK untuk memperbaiki pembelajarannya, karena mereka tidak mampu melaksanakan PTK khususnya pada pembelajaran Seni Budaya. Disamping itu guru-guru juga belum menguasai pembuatan RPP sesuai dengan tuntutan kurikulum 2013. Solusi yang ditawarkan untuk penyelesaian masalah ini adalah dengan melakukan suatu pelatihan dengan pendekatan rancang bangun, penyuluhan, pelatihan, pendampingan/ pembimbingan dari instruktur. Hasil dari kegiatan ini adalah adalah 1) $80 \%$ peserta sudah dapat menguasai pembuatan RPP berdasarkan kurikulum 2013 dengan baik, begitu juga dari segi penguasaan materi PTK, 75\% peserta sudah dapat menguasai pelaksanaan PTK dengan baik.
\end{abstract}

Kata Kunci: Pembelajaran seni budaya, kualitas pembelajaran, RPP dan PTK.

\begin{abstract}
The fundamental problems experienced by cultural arts teachers in Junior High School Sungai Pua, Agam Regency, especially Junior High School number 1 and Junior High School number 2, are in improving the quality of learning, thus impacting on the achievement of student learning outcomes. One of the efforts to improve the quality of learning is by implementing Classroom Action Research (CAR). In general, Junior High Schools' teachers have not implemented CAR yet to improve their learning, because they are not able to carry out CAR especially in the learning of Cultural Arts. Besides that the teachers also have not mastered in making of lesson plans based on the 2013 curriculum. The solutions offered to solve this problem are by conducting training with a design approach, counseling, training and mentoring from the instructor. The results of this activity are 1) $80 \%$ of participants have mastered in making of RPP based on the 2013 curriculum well, as well as in terms of mastering CAR materials, $75 \%$ of participants have mastered the implementation of CAR properly.
\end{abstract}

Keywords: Art and cultural learning, quality of learning, lesson plans and PTK

\section{PENDAHULUAN}

Menurut undang-undang tentang sistim pendidikan nasional, bahwa salah satu kewajiban guru meningkatkan kemampuan profesional sesuai dengan tuntutan perkembangan ilmu pengetahuan dan teknologi serta pembangunan bangsa, maka peningkatan mutu guru merupakan urgensi. Oleh sebab itu semua guru tingkat satuan pendidikan diantaranya adalah Sekolah Menengah Pertama (SMP) harus bisa mengembangkan dirinya agar bisa menjadi guru profesional dan selalu meningkatkan kualitas pembelajarannya. Hal ini berlaku untuk semua guru mata pelajaran.

Salah satu mata pelajaran yang ada pada kurikulum satuan pendidikan atau SMP adalah mata pelajaran Seni Budaya. Mata pelajaran ini masuk kelompok mata pelajaran estetika, yaitu mata pelajaran yang ditujukan untuk meningkatkan kemampuan sensitivitas, ekspresi dan apresiasi keindahan dan harmoni. Kemampuan mengapresiasi dan mengekspresikan keindahan merupakan standar kompetensi yang harus dimiliki siswa. Hal ini sangat berguna, baik dalam kehidupan individual, 


\section{Gorga Jurnal Seni Rupa \\ Volume 07 Nomor 02 \\ p-ISSN: 2301-5942 | e-ISSN: 2580-2380}

sehingga mampu menikmati dan mensyukuri hidup, maupun dalam kehidupan kemasyarakatan, sehingga mampu menciptakan kebersamaan yang harmonis (Lampiran Peraturan Menteri Pendidikan Nasional Nomor 22 Tahun 2006).

Menurut Kurikulum 2013, mata pelajaran Seni Budaya di SMP terdiri dari seni rupa, seni musik, seni tari dan seni teater. Kurikulum mengamanatkan bahwa setiap satuan pendidikan dapat memilih aspek yang diajarkan sesuai dengan kemampuan (guru dan fasilitas) pada satuan pendidikan tersebut (Lampiran Peraturan Menteri Pendidikan Nasional Nomor 22 Tahun 2006). Dari beberapa aspek atau jenis seni yang ada dalam mata pelajaran Seni Budaya, maka SMP kota bukittinggi umumnya memilih dua aspek saja yang diberikan, yakni seni rupa dan seni musik (Hultamarni Ketua MGMP Seni Budaya SMP Agam Timur). Sesuai dengan struktur kurikulum SMP/MTs, mata pelajaran ini harus diajarkan setiap semester dari kelas VII sampai kelas IX kepada seluruh siswa.

Guru yang berwenang untuk mengajarkan mata pelajaran di atas adalah guru yang telah memiliki persyaratan. Sesuai dengan Undang-Undang Nomor 14 tahun 2005 tentang guru dan dosen, dan PP no. 19 tahun 2005 tentang Standar Nasional Pendidikan, bahwa tingkat pendidikan minimal untuk menjadi seorang guru adalah setingkat $\mathrm{S} 1$. Ternyata guru-guru SMPN Padang masih ada yang berlatar belakang pendidikan di bawah $\mathrm{S} 1$. Hal ini dialami oleh SMPN 1 dan SMPN 2 Sungai Pua. Pada SMPN 1 terdapat $11,11 \%$ guru yang berlatar belakang pendidikan S2, 72,22\% guru yang berlatar belakang pendidikan S1, sedangkan $16,67 \%$ lagi guru masih berlatar belakang pendidikan di bawah S1. Sedangkan di SMPN 2 belum ada guru yang berlatar belakang pendidikan S2, 70,59\% berlatar belakang pendidikan S1, sedangkan 29,41\% lagi guru masih berlatar belakang pendidikan di bawah S1 ( Kepala SMPN 1 dan SMPN 2 Sungai Pua). Data ini menunjukkan bahwa masih banyak guruguru dari kedua SMP mitra yang belum memiliki latar belakang pendidikan minimal $\mathrm{S} 1$. Hal ini berarti tingkat pendidikan guru-guru belum sesuai dengan kriteria yang telah ditentukan oleh UndangUndang Guru dan Dosen.

Dalam melaksanakan pembelajaran umumnya guruguru di sekolah mitra mengalami masalah, termasuk guru seni budaya (Indriati, S.Pd. guru SMPN 1 dan Susi Indriani, S.Pd. guru SMPN 2 Sungai Pua). Guru-guru Seni Budaya mengalami masalah terutama dalam memperbaiki kualitas pembelajarannya. sehingga berdampak pada pencapaian hasil belajar siswa. Hal ini terlihat dari hasil belajar yang dicapai siswa pada mata pelajaran Seni Budaya. Berdasarkan informasi pendahuluan yang penulis lakukan di SMPN 1 Sungai Pua, ternyata sebagian besar $(57,69 \%)$ hasil belajar siswa dalam mata pelajaran Seni Budaya $<75$, dan hanya $42,31 \%$ yang berada $>75$. Begitu juga yang terjadi di SMPN 2 Sungai Pua ternyata sebagian besar $(59,65 \%)$ hasil belajar siswa dalam mata pelajaran Seni Budaya $<75$, dan hanya $40,35 \%$ yang berada $>75$. Hal ini berarti hasil belajar siswa dalam mata pelajaran ini belum optimal.

Sebagai guru yang profesional tentu hal ini perlu diperbaiki agar kualitas pembelajaran dapat ditingkatkan dan hasil belajar dapat dioptimalkan. Upaya-upaya ke arah perbaikan pembelajaran adalah sikap profesional guru. Untuk mewujudkan profesional guru dibutuhkan sikap kreatif dan inovatif yang selalu mempunyai keinginan terus menerus untuk memperbaiki dan meningkatkan mutu pembelajarannya.

Untuk memperbaiki dan meningkatkan mutu pembelajaran guru dianjurkan untuk melakukan kegiatan Penelitian Tindakan Kelas (PTK). Berdasarkan informasi yang penulis dapat di sekolah yang dijadikan mitra yakni SMPN 1 dan SMPN 2 Sungai Pua, umumnya guru belum melaksanakan PTK dalam memperbaiki dan meningkatkan mutu proses pembelajaran. Walaupun kegiatan ini diharuskan bagi guru-guru yang akan naik pangkat mulai dari golongan III/b ke atas (Taslim,M.Pd. Kepala SMPN 1 Sungai Pua). Sebagai akibatnya pada umumnya guru-guru sulit untuk naik pangkat, karena ketidak mampuan menulis karya ilmiah, berupa penelitian (termasuk melaksanakan PTK), tulisan ilmiah populer, menulis buku dan diktat. Padahal, aturan kenaikan pangkat guru, mereka memungkinkan dapat naik sampai IV/d. Hal inilah yang menyebabkan guru sulit untuk naik pangkat ke tingkat yang lebih tinggi. Kenyataan di atas mengisyaratkan bahwa salah satu kendala yang dialami guru untuk naik pangkat adalah mereka tidak mampu menulis karya ilmiah dan melaksanakan PTK dalam memperbaiki pembelajarannya di kelas, terutama pada pembelajaran Seni Budaya.

Untuk melaksanakan PTK dituntut RPP yang akan dipedomani dalam pelaksanaan pembelajaran dan akan berkembang sesuai dengan siklus PTK. 


\section{Gorga Jurnal Seni Rupa \\ Volume 07 Nomor 02 \\ p-ISSN: 2301-5942 | e-ISSN: 2580-2380}

Menurut Wardhani (2007) Sebelum mengajar, seoreang guru seyogyanya membuat perencanaan pembelajaran (RPP), baik guru yang mengajar rutin, maupun guru yang mengajar untuk memperbaiki pembelajaran (melakukan PTK). RPP yang dibuat harus disesuaikan dengan tuntutan kurikulum yang berlaku. Kurikulum yang digunakan saat ini adalah kurikulum 2013. Hal ini juga merupakan masalah, karena berdasarkan pengamatan terhadap kinerja guru seni budaya di sekolah mitra (SMPN 1 dan SMPN 2 Sungai Pua), sebanyak 71,43 \% guru masih menggunakan RPP kuriklum 2006 (KTSP), sebanyak $85,71 \%$ RPP yang dibuat guru tidak sesuai dengan tuntutan kurikulum 2013, padahal SMPN mitra telah melaksanakan kurikulum 2013. Tentun saja RPP yang dibuat guru tersebut sulit dipedomani sebagai acuan pelaksanaan pembelajaran di kelas.

Permasalahan di atas perlu segera diatasi, karena untuk meningkatkan kualitas pembelajaran, guru harus bisa meningkatkan kemampuannya dalam melaksanakan pembelajaran. Untuk mengatasinya perlu dilakukan suatu upaya peningkatan kemampuan guru terutama guru Seni Budaya SMP agar proses pembelajaran dapat menjamin hasil belajar yang optimal.

\section{KAJIAN TEORI}

\section{Penelitian Tindakan Kelas (PTK)}

Guru yang profesional selalu meningkatkan kualitas pembelajarannya dan selalu memperbaiki pembelajarannya secara terus menerus. Menurut Sanjaya (2009), guru yang profesional tidak akan merasa puas dengan hasil yang yang telah dicapainya. Untuk itu guru yang profesional akan secara terus menerus menambah dan meningkatkan kemampuannya sesuai dengan tugas dan tanggung jawabnya. Jadi guru yang profesional akan berusaha untuk meningkatkan kualitas pembelajaran. Kualitas pembelajaran akan dapat ditingkatkan apabila guru meningkatkan kualitas kinerjanya.

Salah satu upaya meningkatkan kalitas kinerja guru dan meningkatkan kualitas pembelajaran adalah dengan melaksanakan Penelitian Tindakan Kelas (PTK). Hal ini sesuai dengan yang dikemukan Wardhani (2007) bahwa PTK adalah penelitian yang dilakukan oleh guru di dalam kelasnya sendiri melalui refleksi diri, dengan tujuan untuk memperbaiki kinerjanya sebagai guru, sehingga hasil belajar siswa menjadi meningkat.

Meningkatkan kualitas pembelajaran hanya akan dapat dilakukan manakala guru menyadari adanya masalah yang dihadapi di kelas. Berdasarkan masalah tersebut, guru mencari dan merencanakan program pembelajaran yang dapat memperbaiki dan memecahkan masalah, yang selanjutnya melaksanakan program tersebut secara sistematis dan empiris (Sanjaya, 2009).

Berdasarkan penjelasan di atas dapat dikemukakan, bahwa ciri-ciri dari PTK adalah 1) ada sesuatu yang perlu diperbaiki dalam praktik pembelajaran yang dilakukan selama ini, 2) melalui refleksi diri, 3) dilakukan di dalam kelas dan 4 bertujuan unutk memperbaiki pembelajaradapat dibedakan antara penelitian biasa dengan PTK. Kunci utama dalam PTK adalah adanya tindakan (action) yang dilakukan berulang-ulang dalam rangka mencapai perbaikan yang diinginkan (Wardani, 2007). Salah satu model yang dapat dikembangkan untuk melaksanakan PTK ini adalah model Kurt Lewin. Model ini terdiri dari empat komponen, yaitu; 1) perencanaan, 2) tindakan, pengamatan dan refleksi (Ekawarna, 2010). Model ini dijadikan sebagai acuan pokok dari berbagai moodel PTK.

\section{Rencana Pelaksanaan Pembelajaran (RPP)}

Rencana Pelaksanaan Pembelajaran (RPP) adalah salah satu kegiatan yang dilakukan guru sebelum ia melaksanakan pembelajaran di kelas. Muslich (2008) mengemukakan, bahwa rencana pelaksanaan pembelajaran adalah rancangan pembelajaran mata pelajaran per unit yang akan diterapkan guru dalam pembelajaran di kelas. Selanjutnya Mulyasa (2006) mengungkapkan, bahwa rencana pelaksanaan pembelajaran adalah rencana yang menggambarkan prosedur dan manajemen pembelajaran untuk mencapai satu atau lebih kompetensi dasar (KD). Pada hakekatnya rencana pelaksanaan pembelajaran (RPP) merupakan perencanaan jangka pendek untuk memperkirakan tindakan apa yang akan dilakukan dalam pembelajaran.

Salah satu upaya dalam meningkatkan kualitas pembelajaran, guru harus bisa membuat RPP dengan baik (Uno,2006). Tanpa adanya RPP guru akan sulit melaksanakan proses pembelajaran atau meningkatkan kualitas pembelajaran secara baik, karena RPP itu adalah suatu proses atau penetapan langkah-langkah yang lebih efektif dan efesien agar tujuan dapat dicapai sesuai dengan yang diharapkan (Wisdiarman dan Zubaidah,2014). Jadi kemampuan guru dalam membuat RPP merupakan salah satu faktor keberhasilan guru dalam melaksanakan proses pembelajaran. Disamping itu RPP juga sangat diperlukan dalam melaksanakan PTK. Salah satu yang 


\section{Gorga Jurnal Seni Rupa \\ Volume 07 Nomor 02 \\ p-ISSN: 2301-5942 | e-ISSN: 2580-2380}

harus dipersiapkan guru dalam proses pelaksanaan PTK adalah RPP, sebab RPP yang akan dipedomani dalam pelaksanaan pembelajaran dan akan berkembang sesuai dengan siklus PTK.

RPP yang dibuat guru harus disesuaikan dengan tuntutan kurikulum yang berlaku, yakni kurikulum 2013. Kurikulum 2013 mengisyaratkan bahwa proses pembelajaran dilaksanakan berdasarkan pendekatan ilmiah. Berarti pembuatan RPP juga menggunakan pendekatan ilmiah (scientific) dan kontekstual dalam pembelajaran. Pendekatan ilmiah merupakan kegiatan pembelajaran yang dipandu dengan kaidah-kaidah pendekatan ilmiah seperti; mengamati, bertanya, menalar, menyimpulkan, dan mengkomunikasikan (Wisdiarman, 2017). Sedangkan kontestual adalah suatu pendekatan, dimana dalam pelaksanaan pembelaharan bisa memberikan kesempatan pada siswa untuk aktif, kritis dan kreatif, kegiatan pembelajaran diarahkan agar siswa melakukan sesuatu bukan menghafal, kegiatan pembelajaran harus dekat dengan kehidupan nyata. Oleh sebab itu dalam merencanakan kegiatan pembelajaran ini guru harus bisa memahami pembelajaran dengan pendekatan ilmiah dan kontektual tersebut.

\section{METODE PELAKSANAAN}

Metode untuk mendukung realisasi program PKM ini adalah memberikan pelatihan kepada guru-guru seni budaya SMP Agam Timur, terutama guru-guru SMPN dan SMPN 2 Sungai Pua. Pendekatan yang dilakukan adalah: 1) Rancang bangun; antara lain; a. menulis makalah/bahan pelatihan dan membagikannya pada peserta/ guru sebagai pegangan/pedoman/ referensi bagi mereka dalam memahami materi yang diberikan, b. membuat model/ contoh proposal dan laporan PTK dan c. Membuat contoh RPP sebagai pedoman/contoh dan media pelatihan. Semua hasil rancang bangun ini dibagikan pada peserta untuk dipedomani. 2) Menyajikan materi pelatihan/ penyuluhan; antara lain; a. materi bersifat teori diberikan dengan metode ceramah, tanya jawab dan peragaan, dan menggunakan power point. b. menyajikan materi bersifat praktik diberikan dengan metode demonstrasi dan pemberian tugas. Agar peserta lebih memahami materi ini, instruktur memperlihatkan model proposal dan laporan PTK serta RPP seni budaya. 3) Pelatihan berupa praktik, antara lain; a. pelatihan menulis proposal PTK; kegiatan ini merupakan pengaplikasian pengetahuan yang telah didapatkan guru pada tahap pemahaman materi. Untuk melaksanakan ini peserta ditugaskan membuat proposal PTK dan RPP sesuai dengan tuntutan kurikulum 2013, kemudian dilakukan review proposal yang telah dibuat peserta. 4) Mendampingi/membimbing guru dalam membuat proposal PTK dan RPP seni budaya. Pembimbingan dilakukan secara individual oleh instruktur dan dibantu oleh beberapa orang mahasiswa.

Setelah kegiatan dilaksanakan, selanjutnya dilakukan evaluasi/ ketercapaian tujuan; Evaluasi ketercapaian tujuan dilaksanakan mengacu kepada tujuan yang ditetapkan. Evaluasi ini dilaksanakan pada akhir proses pelatihan dengan maksud untuk mengukur kemampuan peserta baik pengetahuan maupun keterampilannya. Evaluasi ini dilaksanakan dengan cara memberikan tes dan pengamatan terhadap tugas yang dikerjakan peserta.

\section{HASIL DAN PEMBAHASAN}

\section{Hasil Kegiatan}

Program yang dilaksanakan mengacu kepada tujuan yang ditetapkan. Tujuan kegiatan ini adalah meningkatnya kemampuan guru dalam membuat RPP dan PTK seni budaya. Hasil dari evaluasi terhadap kemampuan guru tersebut dapat dilihat pada tabel berikut ini:

Tabel 1. Kemampuan Peserta dalam Membuat RPP

\begin{tabular}{|c|c|c|c|}
\hline \multirow{2}{*}{ Capaian } & \multirow{2}{*}{ Kategori } & \multicolumn{2}{|c|}{ Kemampuan } \\
\cline { 3 - 4 } & & F & $\%$ \\
\hline $90-100$ & Sangat Baik & 1 & 10 \\
\hline $80-89$ & Baik & 7 & 70 \\
\hline $65-79$ & Cukup Baik & 2 & 20 \\
\hline $60-64$ & Kurang Baik & - & - \\
\hline$<60$ & Tidak Baik & - & - \\
\hline & & 10 & 100 \\
\hline
\end{tabular}

Tabel di atas terlihat, bahwa kemampuan peserta dalam menguasai materi strategi pembelajaran; 1 orang $(10 \%)$ yang mendapat nilai antara $90-100$ atau kategori sangat baik, 7 orang $(70 \%)$ yang mendapat nilai 80 - 89 atau kategori baik, dan 2 orang (20\%) yang mendapat nilai 65 - 79 atau kategori cukup baik, sedangkan yang mendapat nilai di bawah 65 atau kategori kurang baik dan tidak baik tidak ditemukan. Hal ini berarti pada umumnya $(80 \%)$ pengetahuan peserta tentang RPP dalam kategori baik dan sangat baik. 


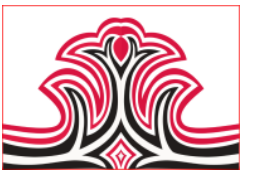

Tabel 2. Kemampuan Peserta dalam PTK

\begin{tabular}{|c|c|c|c|c|c|}
\hline \multirow{2}{*}{ Capaian } & \multirow{2}{*}{ Kategori } & \multicolumn{4}{|c|}{ Kemampuan } \\
\cline { 3 - 6 } & & \multicolumn{2}{|c|}{ Teori } & \multicolumn{2}{c|}{ Praktik } \\
\cline { 3 - 6 } & & F & $\%$ & F & $\%$ \\
\hline $90-100$ & SB & 2 & 20 & 1 & 10 \\
\hline $80-89$ & B & 6 & 60 & 6 & 60 \\
\hline $65-79$ & CB & 2 & 20 & 2 & 20 \\
\hline $60-64$ & KB & & & 1 & 10 \\
\hline$<60$ & TB & - & - & - & - \\
\hline & & 10 & 100 & 10 & 100 \\
\hline
\end{tabular}

Tabel di atas terlihat, bahwa kemampuan guru dalam materi teori PTK, 2 orang (20\%) yang mendapat nilai antara $90-100$ atau kategori sangat baik, 6 orang $(60 \%)$ yang mendapat nilai $80-89$ atau kategori baik, dan 2 orang (20\%) yang mendapat nilai $65-79$ atau kategori cukup baik, sedangkan yang mendapat nilai di bawah 64 atau kategori kurang baik tidak ditemukan. Hal ini berarti pada umumnya $(80 \%)$ kemampuan peserta tentang materi teori PTK dalam kategori baik dan sangat baik.

Begitu juga dengan kemampuan peserta dalam praktik/ melaksanakan PTK, terlihat bahwa 1 orang (10\%) guru yang mendapat nilai antara $90-100$ atau kategori sangat baik, 6 orang $(60 \%)$ yang mendapat nilai 80 - 89 atau kategori baik, 2 orang (20\%) yang mendapat nilai 65 - 79 atau kategori cukup baik dan 1 orang (10\%) mendapat nilai $60-64$, sedangkan yang mendapat nilai di bawah 60 tidak ditemukan. Hal ini berarti sebahagian besar (70\%) kemampuan peserta dalam melaksanakan PTK dalam kategori baik. Bila dihitung rata-rata kemampan guru dalam teori dan praktik PTK, ternyata $75 \%$ guru telah menguasai PTK dengan baik.

\section{Pembahasan Kegiatan}

Berdasarkan temuan ini, maka tujuan kegiatan atau target kegiatan sudah tercapai dengan baik. Temuan ini menunjukkan bahwa $77,5 \%$ guru-guru sudah menguasai cara pembuatan RPP sesuai dengan tuntutan kurikulum 2013 dan pelaksanaan PTK dengan baik. Capaian ini telah melampaui target yang ditetapkan yakni $75 \%$ guru sudah menguasai materi pelatihan.Hal ini menunjukkan bahwa guru-guru sudah menunjukkan prestasi yang mengembirakan, walaupun belum pada kategori yang sangat baik.

Ketercapaian tujuan dapat dilihat dari perbandingan kemampuan guru sebelum diadakan kegiatan (kemampuan awal) dengan kemampuan guru setelah dilakukan kegiatan. Kemampuan awal guru dalam membuat RPP dan pelaksanaan PTK seni budaya masih rendah. Tetapi setelah diberikan pelatihan dan diberikan evaluasi akhir, maka terjadi peningkatan kemampuan/pemahaman guru dalam membuat RPP
Gorga Jurnal Seni Rupa

Volume 07 Nomor 02

p-ISSN: 2301-5942 | e-ISSN: 2580-2380

dan pelaksanaan PTK. Hal ini dapat dilihat dari rekapitulasi hasil kegiatan pada tabel berikut ini:

Tabel 3. Rekapitulasi Kemampuan Guru dalam Pembuatan RPP dan Pelaksanaan PTK Seni Budaya

\begin{tabular}{|c|c|c|c|c|c|c|c|}
\hline \multirow{3}{*}{ Capaian } & \multirow{2}{*}{ Kategori } & \multicolumn{2}{|c|}{$\begin{array}{c}\text { Kembuatan } \\
\text { RPP }\end{array}$} & \multicolumn{4}{|c|}{ Pelaksanaan PTK } \\
\cline { 3 - 8 } & & \multicolumn{2}{|c|}{ Teori } & \multicolumn{2}{c|}{ Praktik } \\
\cline { 3 - 8 } & & F & $\%$ & F & $\%$ & F & $\%$ \\
\hline $90-100$ & SB & 1 & 10 & 2 & 20 & 1 & 10 \\
\hline $80-89$ & B & 7 & 70 & 6 & 60 & 6 & 60 \\
\hline $65-79$ & CB & 2 & 20 & 2 & 20 & 2 & 20 \\
\hline $60-64$ & KB & - & - & & & 1 & 10 \\
\hline$<60$ & TB & - & - & - & - & - & - \\
\hline & & 10 & 100 & 10 & 100 & 10 & 100 \\
\hline
\end{tabular}

Tabel di atas menunjukkan bahwa ternyata $80 \%$ guru, tingkat kemampuannya dalam membuat RPP sudah dalam kategori baik. Begitu juga kemampuan guru dalam pelaksanaan PTK, ternyata $(75 \%)$ sudah dalam kategori baik. Berarti tingkat kemampuan guru terhadap kedua aspek tersebut sudah baik, walaupun belum pada kategori sangat baik. Namun target dari kegiatan ini sudah tercapai, yakni minimal $75 \%$ guruguru dapat menguasai materi pelatihan.

Temuan di atas menunjukkan bahwa guru-guru telah dibekali dengan kemampuan untuk meningkatkan kualitas pembelajaran. Salah satu upaya dalam meningkatkan kualitas pembelajaran, guru harus bisa membuat RPP dengan baik (Uno,2006). Tanpa adanya RPP guru akan sulit melaksanakan proses pembelajaran atau meningkatkan kualitas pembelajaran secara baik, karena RPP itu adalah suatu proses atau penetapan langkah-langkah yang lebih efektif dan efesien agar tujuan dapat dicapai sesuai dengan yang diharapkan (Wisdiarman dan Zubaidah,2014). Jadi kemampuann guru dalam membuat RPP merupakan salah satu faktor keberhasilan guru dalam melaksanakan proses pembelajaran. Disamping itu RPP juga sangat diperlukan dalam melaksanakan PTK. Salah satu yang harus dipersiapkan guru dalam proses pelaksanaan PTK adalah RPP, sebab RPP yang akan dipedomani dalam pelaksanaan pembelajaran dan akan berkembang sesuai dengan siklus PTK.

Dalam meningkatkan kualitas pembelajaran, seorang guru disamping kemampuan guru dalam membuat RPP, guru juga harus memiliki kemampuan dalam melaksanakan PTK. Sebab dengan PTK guru dapat meningkatkan kinerjanya secara terus menerus, sehingga dia dapat memperbaiki pembelajarannya untuk mencapai hasil belajar siswa yang maksimal (Sanjaya, 2009).

Terjadinya peningkatan kemampuan guru-guru dalam dua aspek yang telah dijelaskan dia atas, menunjukkan bahwa kegiatan pengabdian kepada masyarakat yang 


\author{
Gorga Jurnal Seni Rupa \\ Volume 07 Nomor 02 \\ p-ISSN: 2301-5942 | e-ISSN: 2580-2380
}

telah dilaksanakan telah berhasil dengan baik. Disamping itu yang menjadi indikator keberhasilan kegiatan ini adalah; 1) semua program yang dirancang dapat dilaksanakan, tanpa ada hambatan atau kendala yang berarti, walaupun ada kendala, tetapi sudah diatasi, 2) peserta dalam mengikuti kegiatan penuh semangat dan motivasi yang tinggi. Hal ini ditandai dengan keseriusan mereka dalam kegiatan, bersemangat dalam belajar, aktif dalam bertanya, mematuhi semua petunjuk yang ada, dan berlatih serius dan tekun. Mungkin ini disebabkan karena materi pelatihan ini belum pernah didapatkan oleh guru-guru, apalagi PTK merupakan kegiatan wajib bagi guru untuk kenaikan pangkatnya. Disamping itu dukungan Kepala SMPN mitra sangat besar sekali.

Sebagai kendala dari pelaksanaan program ini adalah kurangnya pegetahuan peserta/guru seni budaya terhadap materi seni budaya (seni rupa, seni musik dan seni tari), sehingga agak sulit bagi guru dalam mengembangkan materi pada pelaksanaan PTK. Disamping itu kurangnya pengetahuan peserta/guru dengan strategi pembelajaran yang inovatif yang akan dijadikan sebagai solusi dari perbaikan pembelajaran.

Untuk mengatasi atau tindak lanjut yang bisa dilakukan adalah dengan memberikan referensi tentang materi seni budaya (seni rupa, seni musik dan seni tari) dan referensi tentang strategi pembelajaran seni budaya yang inovatif. Disamping itu para peserta dianjurkan mencari referensi lain di internet.

\section{KESIMPULAN DAN SARAN}

\section{Kesimpulan}

Kesimpulan yang dapat diperoleh dari pelaksanaan program pengabdian kepada masyarakat dalam bentuk Program Kemitraan Masyarakat (PKM) adalah:

1. Pada umumnya (80\%) guru-guru SMPN SMPN 1 dan SMPN 2 Sungai Pua sudah menguasai pembuatan RPP dengan baik,

2. Pada umumnya (75\%) guru-guru SMPN SMPN 1 dan SMPN 2 Sungai Pua sudah menguasai pelaksanakan PTK dengan baik.

\section{Saran}

Berdasarkan kesimpulan yang dikemukakan di atas, berikut ini akan dikemukakan pula beberapa saran sebagai berikut:

1. Diperlukan adanya kontiniutas dalam mengaplikasikan pengetahuan dan keterampilan yang diperoleh guru-guru SMPN mitra. Apabila kegiatan ini tidak dilakukan secara terus menerus, maka pengetahuan dan keterampilan yang telah diperoleh akan menjadi tidak berarti.
2. Diharapkan peserta pelatihan ini dapat menyebar luaskan keterampilan yang telah diperolehnya kepada teman-temannya yang lain yang kebetulan tidak mengikuti, sehingga seluruh guru dapat pula meningkatkan pengetahuan dan keterampilannya dalam pelaksanaan PTK.

3. Diharapkan pada instansi terkait agar membuat program lanjutan, dan memberikan pelatihan terhadap materi yang belum tersentuh pada kegiatan PKM ini.

\section{DAFTAR RUJUKAN}

Ekawarna. (2010) Penelitian Tindakan Kelas. Jakarta: Gaung Persada Press. Bekerjasama dengan FKIP Universitas Jambi.

Muslich, Masnur.(2009). Melaksanakan PTK Itu Mudah. Jakarta: Bumi Aksara. Peraturan Pemerintah Nomor 19 tahun 2005 tentang Standar Nasional Pendidikan.

Sanjaya, Wina (2009). Penelitian Tindakan Kelas. Jakarta: Kencana Prenada Media Group.

Uno, Hamzah B. (2006). Perencanaan Pembelajaran. Jakarta:Bumi Aksara.

Wardhani. (2007). Penelitian Tindakan Kelas. Jakarta: Universitas Terbuka.

Wisdiarman dan Zubaidah. (2014). Pembelajaran Berbasis Kurikulum 2013. Padang: Seni Rupa FBS UNP Padang. (2017). Analisis Kebutuhan LKS Berbasis Pendekatan Saintifik Dengan Model Discovery Learning Pada Mata Pelajaran Seni Budaya Materi Seni Rupa di 2017. Hal.80-89 SMP. Jurnal Komposisi.Volume XVIII.No.1 